\title{
STUDENT PERCEPTIONS OF ONLINE LEARNING DURING THE COVID- 19 PANDEMIC
}

\author{
Awal Kurnia Putra Nasution', Nurul Qomariah Ahmad ${ }^{2}$ \\ 1,2 IAIN Takengon, Aceh Tengah, Indonesia \\ Email: awalkpn@gmail.com ${ }^{1}$, qomariyahnrl@gmail.com²
}

\begin{abstract}
Online learning has been chosen to be applied in all tertiary institutions in Indonesia; this also applies to IAIN Takengon. Student perception is one of the determinants of the success of the learning that is carried out. The purpose of writing this article is to find out how students' perceptions of online learning have been implemented and the factors that influence these perceptions. The research method used is an online survey using google form. The results showed that students' perceptions of online learning were not very good; this was caused by several factors, such as poor internet access, burdensome internet quota, difficulty communicating with lecturers, so students were not ready to use applications when online learning was carried out. There needs to be much improvement in the online learning system implemented; this indicates that universities are not ready to carry out online lectures.
\end{abstract}

Keywords: Perception, Online Learning, The Covid-19 Pandemic

\begin{abstract}
Abstrak: Pembelajaran daring merupakan pembelajaran yang dipilih untuk diterapkan diseluruh perguruan tinggi di Indonesia, hal ini juga berlaku di IAIN Takengon. Persepsi mahasiswa adalah salah satu penentu keberhasilan pembelajaran yang dilaksanakan. Tujuan penulisan artikel ini adalah untuk mengetahui bagaimana persepsi mahasiswa terhadap pembelajaran daring yang telah dilaksanakan serta faktor-faktor yang mempengaruhi persespsi tersebut. Metode penelitian yang digunakan adalah survey online dengan memanfaatkan google form. Hasil penelitian menunjukkan bahwa persepsi mahasiswa terhadap pembelajaran daring tidak begitu baik, hal ini disebabkan oleh beberapa faktor, seperti akses internet yang kurang baik, kuota internet yang membebani, kesulitan berkomunikasi dengan dosen, hingga belum siapnya mahasiswa dalam menggunakan aplikasi saat pembelajaran daring dilaksanakan. Perlu banyak perbaikan dalam sistem pembelajaran online yang sudah dilaksanakan, hal ini menandakan bahwa perguruan tinggi belum siap dalam melaksanakan perkuliahan secara daring.
\end{abstract}

Kata Kunci: Persepsi, Pembelajaran Daring, Pandemi Covid-19

\section{INTRODUCTION}

Online learning is an option for conducting lectures during the Covid-19 pandemic in all universities in Indonesia (Kemendikbud, 2020); IAIN Takengon is no exception. This online lecture policy was taken to keep the Covid-19 virus spread due to crowds caused by lectures being held in class (Dhawan, 2020). At IAIN Takengon, online lectures are conducted from the beginning of March 2020 until the end of the semester for the 2019/2020 academic year in July 2020. Online lectures are carried out by utilizing various learning media, such as the WhatsApp application, Edmodo, google classroom, google meet, zoom, and telegram.

The quality of education in tertiary institutions can be seen from learning outcomes and assessed from students' perceptions of learning (Griffith, 2002). Students' perceptions 
are very important for learning motivation so that learning that takes place can be improved in quality (Koohang \& Durante, 2003). Students' negative perceptions can lead to poor learning outcomes and decreased learning motivation and persistence (Kauffman, 2015). Research conducted by Bali \& Liu shows that students feel comfortable implementing online learning; this is because students can learn technological innovation (Bali \& Liu, 2018). Students have a positive view of online learning, even though online learning can only be used as an adjunct to face-to-face learning (Asiry, 2017). In research conducted by Almaghas, it is shown that students are more comfortable choosing face-toface lectures than online lectures (Almaghaslah et al., 2018). Based on some of these studies, it is feared that lectures' discomfort will negatively affect the learning being carried out. The purpose of writing this article is to find out students' perceptions of online learning and to identify difficulties in online learning. In the end, this description of student perceptions will be used as an evaluation material for online lectures to make improvements in the implementation of subsequent lectures.

\section{LITERATURE REVIEW}

\section{Student Perception}

Perception is an individual's view of other people who play a role in his life and can be one of the determining factors for success, which also applies to students (Corbin et al., 2020). It is indicated that if the individual has a good view of something or other people, it will also benefit him/herself. Perception can also be considered an individual's interpretation of something (Amir et al., 2020). This opinion is in line with that expressed by Arifin, that perception is a process of giving meaning, interpretation of stimuli and sensations received by individuals, and is strongly influenced by internal and external factors of each individual (Hadi et al., 2017). The results of research conducted by Van Leeuwenkamp et al. show that students' perceptions of the effects of assessment on learning are positively related to learning approaches and learning outcomes (Gerritsenvan Leeuwenkamp et al., 2019). Based on this opinion, it can be said that perception is a person's view in his mind about something that can affect the five senses in attitude.

\section{Online Learning}

Online learning is a learning process between students and teachers/instructors not face to face directly but using electronic media in the internet network simultaneously in different places (Singh \& Thurman, 2019). With online learning, it is expected that 
students' role in the learning process will increase because it is not limited by time and space (Saifuddin, 2018). Technological developments have led to more applications that support online learning, such as WhatsApp, google meet, google classroom, zoom, and Edmodo. Each of these applications has advantages. Whatsapp is used by individuals and individuals who have the function of socializing and delivering messages (Trisnani, 2017), but not limited to that WhatsApp is used by teachers to transfer knowledge to students directly and can even take advantage of voice recording and video call features (Baguma et al., 2019). Google classroom is an application that creates classrooms in cyberspace by facilitating communication between educators and students because they can collect, distribute and assess assignments at home or anywhere without being bound by time limits or class hours (Nirfayanti \& Nurbaeti, 2019). Edmodo is specifically designed to be used by teachers and students to facilitate the teaching and learning process, communicate and collaborate and share content in the form of text, images, videos, links, or audio (Mafulah \& Wilujeng, 2018).

\section{RESEARCH METHODOLOGY}

The research method used is an online survey. Data about student perceptions were collected using a questionnaire using google form. When the research was carried out in July 2020, which coincided with the end of lectures in the even semester of the 2019/2020 school year, this was done so that the data obtained could fully describe student perceptions during the initial to the end of online lectures at IAIN Takengon. The number of students who became the source of research data was 216 students from 7 study programs in the Tarbiyah department at IAIN Takengon. The number of detailed respondent data in each study program can be seen in table 1 .

Table 1. Number of respondents for each study program

\begin{tabular}{lc}
\multicolumn{1}{c}{ Study program } & Number of Respondents \\
\hline Islamic education & 57 \\
\hline Arabic & 4 \\
\hline English & 13 \\
\hline Mathematics & 12 \\
\hline Islamic Education Management & 37 \\
\hline Madrasah Ibtidaiyah Teacher Education & 67 \\
\hline Early Childhood Islamic Education & 26 \\
\hline \multicolumn{2}{c}{ Amount } \\
\hline
\end{tabular}


Questions about student perceptions are arranged by adjusting the conditions of online lectures, which consist of 12 questions that will describe how students' perceptions during online lectures have been held for one semester with 16 meetings. The questions will explore students' perceptions about online learning's suitability with the Covid-19 pandemic conditions and whether online learning can help the lecture process.

\section{FINDINGS AND DISCUSSION}

In the first question, online learning is following current conditions, data obtained by ten students or $4.63 \%$ answered strongly disagree, 44 students or $20.37 \%$ answered Disagree, 48 students or $22.22 \%$ answered doubt, 102 students or 47, 22\% answered Agree, and 12 students or $5.56 \%$ answered Strongly agreed. Based on this answer, if the answers are combined agree and strongly agree, the answers obtained by more than half of the students agree or $52.78 \%$ that online learning is applied according to pandemic conditions. This percentage is in the less convincing category because only half of the students have a good perception of the application of online learning, with conditions like this it shows that students feel uncomfortable with applied online learning. According to Smith, two factors determine student learning success in higher education, namely learning management and the convenience of learning online (Smith et al., 2003). Based on this, it is feared that students will not truly succeed in their learning.

In the second question, online learning helps the smooth process of lectures, data obtained from 31 students or $14.35 \%$ answered strongly disagree, 67 students or $31.02 \%$ answered Disagree, 43 students or $19.91 \%$ answered doubt, 70 students or $32.41 \%$ answered Agree, and five students or $2.31 \%$ answered Strongly agreed. Based on these results, the percentage of students agreeing and disagreeing has a slight difference, namely $32.41 \%$ and $31.02 \%$, with a difference of $1.39 \%$ or only three students. When combined, the answers strongly disagree, disagree, and doubt, and the percentage will be $65.28 \%$; this is a very large percentage, this shows that students feel that online learning does not help the smooth process of lectures.

In the third question, I was burdened with the quota for online lectures, data obtained by ten students or 4.63 answered strongly disagree, three students or $1.39 \%$ answered Disagree, 22 students or $10.19 \%$ answered doubt, 75 students or $34.72 \%$ answered Agree, and 106 students or $49.97 \%$ answered Strongly agreed. In this answer's results, if the answers are combined agree and strongly agree, a very large percentage will 
be obtained; namely, $84.69 \%$ of students feel burdened by internet quotas when learning is carried out online. It is a very unfavourable condition for the future lecture process because students' perceptions are not good in terms of internet quota. According to Tsai, students' perceptions of the internet shape student attitudes and online behaviour (Tsai \& Lin, 2004). When referring to this opinion, online behaviour and student attitudes in learning will be greatly affected and are in poor condition.

In the fourth question, Signal Quality hinders me in online lectures, data obtained by ten students or 4.63 answered strongly disagree, three students or $1.39 \%$ answered Disagree, 22 students or $10.19 \%$ answered doubt, 75 students or $34.72 \%$ answered Agree, and 106 students or $49.97 \%$ answered Strongly agreed. In the fifth question, difficulties in using online applications, data obtained from 1 student or $0.46 \%$ answered strongly disagree, 41 students or $18.98 \%$ answered Disagree, 58 students or $26.85 \%$ answered doubt, 74 students or $34.26 \%$ answered Agree, and 42 students or $19.44 \%$ answered Strongly agree. Based on the data above, it can be seen that students still have difficulty using online learning applications. Research conducted by Hung found that students' level of readiness in using computer and internet applications will affect student motivation in learning (Hung et al., 2010). The difficulty of using online learning applications will affect student motivation in learning, so, likely, students will not be very successful in lectures.

In the sixth question, the suitability of online course material with the syllabus, data obtained from 13 students or $6.02 \%$ answered strongly disagree, 34 students or $15.74 \%$ answered Disagree, 54 students or $25 \%$ answered doubt, 111 students or 51, 39\% answered Agree, and four students or $1.85 \%$ answered Strongly agreed. On this question, more than half of the students answered that online lecture teaching materials were following the syllabus; this is a positive and good thing. Appropriate lecture materials will affect student learning outcomes (Khoza, 2013).

In the seventh question, I understand the material provided by the lecturer during online lectures, obtained data from 4 students or $1.85 \%$ who answered strongly disagree, 68 students or $31.48 \%$ answered Disagree, 103 students or $47.69 \%$ answered Doubt- In doubt, 40 students or $18.52 \%$ answered Agree, and one student or $0.46 \%$ answered Strongly agreed. In this question, the most dominant answer is doubt; here, students are not sure that they can understand the lecturer's online lecture material. 
In my 8th question, I find it difficult to handle the time to teach online; it was seen that there was no big disagreement, 23 or 10.65 percent responded to disagreement, 43 or 19.91 students answered concerns, 99 or 45 students, 83 percent replied and 51 or 23.61 percent replied strongly. In this answer, it is very dominant; it can be seen that students have difficulty managing lecture time; this can be due to the improper time for online lectures, which are carried out with a predetermined class schedule.

In the ninth question, difficulty communicating with lecturers during online lectures, obtained data from 1 student or $0.46 \%$ answered strongly disagree, 32 students or $14.81 \%$ answered Disagree, 50 students or $23.15 \%$ answered doubt, 93 students or 43.06\% answered Agree, and 40 students or $18.52 \%$ answered Strongly agreed. In this result, it can be seen that students are still not ready to communicate online with lecturers; this is evidenced by the number of agreeing and disagree answers, which when combined reach 61.58 .

In the tenth question, difficulty finding references or reading material during online lectures, data obtained from 1 student or $0.46 \%$ answered strongly disagree, 83 students or $38.43 \%$ answered Disagree, 30 students or $13.89 \%$ answered Doubtfully, 14 students or $6.48 \%$ answered Agree, and 88 students or $40.74 \%$ answered Strongly agreed. In answer to this question, students have difficulty finding references or reading material to support the lecture process; this can be caused due to limited library access and limited internet signal.

In the eleventh question, difficulties in doing assignments during online lectures, obtained data from 3 students or $1.39 \%$ answered strongly disagree, 20 students or $9.26 \%$ answered Disagree, 42 students or $19.44 \%$ answered doubt, 87 students or $40.28 \%$ answered Agree, and 64 students or $29.63 \%$ answered Strongly agreed. In the twelfth question, difficulty collecting assignments during online lectures, data obtained from 4 students or $1.85 \%$ answered strongly disagree, 45 students or $20.83 \%$ answered Disagree, 43 students or $19.91 \%$ answered Doubtfully, 85 students or $39.35 \%$ answered Agree, and 39 students or $18.06 \%$ answered Strongly agreed. For both questions, it appears that students are not ready to study online; this can be caused by the absence of adequate training on the implementation of online lectures. Students' technical difficulties, such as difficulties in doing assignments, will affect the learning process's effectiveness (Adnan \& Anwar, 2020). Based on this, it is feared that the learning that has been taking place and that will be carried out in the following semester will run less effectively, so that 
many improvements are needed in the technical implementation of online lectures. For more details, all questions and the frequency of student answers can be seen in table 2 .

Table 2. Student perceptions

\begin{tabular}{|c|c|c|c|c|c|c|}
\hline \multirow[t]{2}{*}{ Question } & \multicolumn{6}{|c|}{ Answer Frequency } \\
\hline & SD & DA & NS & A & SA & $\begin{array}{l}\text { Number of } \\
\text { Responses }\end{array}$ \\
\hline $\begin{array}{l}\text { Online learning } \\
\text { according to current } \\
\text { conditions }\end{array}$ & 10 & 44 & 48 & 102 & 12 & 216 \\
\hline Percentage (\%) & 4,63 & 20,37 & 22,22 & 47,22 & 5,56 & \\
\hline $\begin{array}{l}\text { Online learning helps the } \\
\text { smooth process of } \\
\text { lectures }\end{array}$ & 31 & 67 & 43 & 70 & 5 & 216 \\
\hline Percentage (\%) & 14,35 & 31,02 & 19,91 & 32,41 & 2,31 & \\
\hline $\begin{array}{l}\text { I am burdened with } \\
\text { quotas for online lectures }\end{array}$ & 10 & 3 & 22 & 75 & 106 & 216 \\
\hline Percentage (\%) & 4,63 & 1,39 & 10,19 & 34,72 & 49,07 & \\
\hline $\begin{array}{l}\text { Signal Quality is holding } \\
\text { me back from my online } \\
\text { lectures }\end{array}$ & 15 & 0 & 33 & 87 & 81 & 216 \\
\hline Percentage (\%) & 6,94 & 0,00 & 15,28 & 40,28 & 37,50 & \\
\hline $\begin{array}{l}\text { Difficulty using online } \\
\text { applications }\end{array}$ & 1 & 41 & 58 & 74 & 42 & 216 \\
\hline Percentage $(\%)$ & 0,46 & 18,98 & 26,85 & 34,26 & 19,44 & \\
\hline $\begin{array}{l}\text { The suitability of online } \\
\text { lecture material with the } \\
\text { syllabus }\end{array}$ & 13 & 34 & 54 & 111 & 4 & 216 \\
\hline Percentage (\%) & 6,02 & 15,74 & 25,00 & 51,39 & 1,85 & \\
\hline $\begin{array}{l}\text { I understand the material } \\
\text { provided by the lecturer } \\
\text { during online lectures }\end{array}$ & 4 & 68 & 103 & 40 & 1 & 216 \\
\hline Percentage (\%) & 1,85 & 31,48 & 47,69 & 18,52 & 0,46 & \\
\hline $\begin{array}{l}\text { I have a hard time } \\
\text { managing online lectures }\end{array}$ & 0 & 23 & 43 & 99 & 51 & 216 \\
\hline Percentage (\%) & 0,00 & 10,65 & 19,91 & 45,83 & 23,61 & \\
\hline $\begin{array}{l}\text { Difficulty } \\
\text { communicating with } \\
\text { lecturers during online } \\
\text { lectures }\end{array}$ & 1 & 32 & 50 & 93 & 40 & 216 \\
\hline Percentage (\%) & 0,46 & 14,81 & 23,15 & 43,06 & 18,52 & \\
\hline $\begin{array}{l}\text { Difficulty finding } \\
\text { references or reading } \\
\text { material during lectures } \\
\text { online }\end{array}$ & 1 & 83 & 30 & 14 & 88 & 216 \\
\hline Percentage (\%) & 0,46 & 38,43 & 13,89 & 6,48 & 40,74 & \\
\hline Difficulty doing & 3 & 20 & 42 & 87 & 64 & 216 \\
\hline
\end{tabular}




\begin{tabular}{lrrrrrr}
\hline $\begin{array}{l}\text { assignments during } \\
\text { online lectures }\end{array}$ & & & & & & \\
\hline \multicolumn{1}{c}{ Percentage (\%) } & 1,39 & 9,26 & 19,44 & 40,28 & 29,63 & \\
\hline $\begin{array}{l}\text { Trouble collecting } \\
\text { assignments during } \\
\text { online lectures }\end{array}$ & 4 & 45 & 43 & 85 & 39 & 216 \\
\hline \multicolumn{1}{c}{ Percentage (\%) } & 1,85 & 20,83 & 19,91 & 39,35 & 18,06 \\
\hline
\end{tabular}

Information:

SD: Strongly Disagree

DA: Do not Agree

NS: Not Sure

A: Agreed

SA: Strongly Agree

\section{CONCLUSIONS}

Students' perceptions of online learning are not very good; this can be seen from only half the number of students who feel that online learning is following the current situation and are not sure that students about online learning can help the lecture process. Many factors cause this: student burden of internet quota, difficulties in internet access, difficulty communicating with lecturers, difficulty doing and collecting assignments, and unpreparedness of students in participating in online learning. The number of student difficulties in online learning requires special attention, considering that there is no possibility that lectures will be conducted face-to-face. It is necessary to develop a good and appropriate online learning system so that the problems that arise during online learning can be overcome.

\section{REFERENCES}

Adnan, M., \& Anwar, K. (2020). Online learning amid the COVID-19 pandemic: Students' perspectives. Journal of Pedagogical Sociology and Psycholog, 2(1), 4551. https://eric.ed.gov/?id=ED606496

Almaghaslah, D., Ghazwani, M., Alsayari, A., \& Khaled, A. (2018). Pharmacy students' perceptions towards online learning in a Saudi Pharmacy School. Saudi Pharmaceutical Journal, 26(5), 617-621. https://doi.org/10.1016/j.jsps.2018.03.001

Amir, M. F., Fediyanto, N., Rudyanto, H. E., Nur Afifah, D. S., \& Tortop, H. S. (2020). Elementary students' perceptions of 3Dmetric: A cross-sectional study. Heliyon, 6(6), e04052. 
https://doi.org/10.1016/j.heliyon.2020.e04052

Asiry, M. A. (2017). Dental students' perceptions of an online learning. Saudi Dental Journal, 29(4), 167-170.

https://doi.org/10.1016/j.sdentj.2017.03.005

Baguma, R., Bagarukayo, E., Namubiru, P., Brown, C., \& Mayisela, T. (2019). Using WhatsApp in Teaching to Develop Higher Order Thinking Skills-a Literature Review Using the Activity Theory Lens. International Journal of Education and Development Using Information and Communication Technology (IJEDICT), 15(2), 98-116.

https://eric.ed.gov/?id=EJ1220764

Bali, S., \& Liu, M. C. (2018). Students' perceptions toward online learning and face-toface learning courses. Journal of Physics: Conference Series, 1108(1), 012094. https://doi.org/10.1088/1742-6596/1108/1/012094

Corbin, C. M., Downer, J. T., Ruzek, E. A., Lowenstein, A. E., \& Brown, J. L. (2020). Correlates of change in elementary students' perceptions of interactions with their teacher. Journal of Applied Developmental Psychology, 69, 101144. https://doi.org/10.1016/j.appdev.2020.101144

Dhawan, S. (2020). Online Learning: A Panacea in the Time of COVID-19 Crisis. Journal of Educational Technology Systems, 49(1), 5-22. https://doi.org/10.1177/0047239520934018

Gerritsen-van Leeuwenkamp, K. J., Joosten-ten Brinke, D., \& Kester, L. (2019). Students' perceptions of assessment quality related to their learning approaches and learning outcomes. Studies in Educational Evaluation, 63, 72-82. https://doi.org/10.1016/j.stueduc.2019.07.005

Griffith, J. (2002). Is quality/effectiveness an empirically demonstrable school attribute? Statistical aids for determining appropriate levels of analysis. School Effectiveness and School Improvement, 13(1), 91-122. https://doi.org/10.1076/sesi.13.1.91.3441

Hadi, A. S., Ikhsan, F., \& Engkus, K. (2017). Analisis Faktor yang Mempengaruhi Persepsi Mahasiswa terhadap Keberadaan Perda Syariah di Kota Serang. Jurnal Penelitian Komonikasi Dan Opini Publik, 21(1), 88-101. https://www.neliti.com/id/publications/123770/factor-analysis-that-effectuniversity-student-perception-in-untirta-about-exist

Hung, M. L., Chou, C., Chen, C. H., \& Own, Z. Y. (2010). Learner readiness for online learning: Scale development and student perceptions. Computers and Education, 55(3), 1080-1090. https://doi.org/10.1016/j.compedu.2010.05.004

Kauffman, H. (2015). A review of predictive factors of student success in and satisfaction with online learning. Research in Learning Technology, 23, 1-13. https://doi.org/10.3402/rlt.v23.26507

Kemendikbud, H. D. P. T. (2020). Praktik Baik Pembelajaran Daring di Perguruan Tinggi Masa Pandemi Covid-19. Siaran Pers Nomor : 030/Sipers/IV/2020.

Khoza, S. B. (2013). Learning Outcomes as understood by 'Publishing Research' facilitators at a South African university. Mevlana International Journal of Education, 3(2), 1-11. 
https://doi.org/10.13054/mije.13.09.3.2

Koohang, A., \& Durante, A. (2003). Learners' Perceptions toward the Web-based Distance Learning Activities/Assignments Portion of an Undergraduate Hybrid Instructional Model. Journal of Information Technology Education: Research, 2, 105-113.

https://doi.org/10.28945/316

Mafulah, S., \& Wilujeng, T. T. R. (2018). Pelatihan Pengenalan Aplikasi Pembelajaran Edmodo bagi Mahasiswa Universitas Kanjuruhan Malang. JPM (Jurnal Pemberdayaan Masyarakat), 3(1), 228-238.

https://doi.org/10.21067/jpm.v3i1.2663

Nirfayanti, N., \& Nurbaeti, N. (2019). Pengaruh Media Pembelajaran Google Classroom Dalam Pembelajaran Analisis Real Terhadap Motivasi Belajar Mahasiswa. Proximal Jurnal Penelitian Matematika Dan Pendidikan Matematika, 2(1), 50-59. https://e-journal.my.id/proximal/article/view/211

Saifuddin, M. F. (2018). E-Learning dalam Persepsi Mahasiswa. Jurnal VARIDIKA, 29(2), 102-109.

https://doi.org/10.23917/varidika.v29i2.5637

Singh, V., \& Thurman, A. (2019). How Many Ways Can We Define Online Learning? A Systematic Literature Review of Definitions of Online Learning (1988-2018). American Journal of Distance Education, 33(4), 289-306. https://doi.org/10.1080/08923647.2019.1663082

Smith, P. J., Murphy, K. L., \& Mahoney, S. E. (2003). Towards identifying factors underlying readiness for online learning: An exploratory study. International Journal of Phytoremediation, 24(1), 57-67.

https://doi.org/10.1080/01587910303043

Trisnani. (2017). Pemanfaatan Whatsapp Sebagai Media Komunikasi Dan Kepuasan Dalam Penyampaian Pesan Di Kalangan Tokoh Masyarakat. Jurnal Komunika: Jurnal Komunikasi, Media Dan Informatika, 6(3), 1-12. https://doi.org/10.31504/komunika.v6i3.1227

Tsai, C. C., \& Lin, C. C. (2004). Taiwanese adolescents' perceptions and attitudes regarding the internet: Exploring gender differences. Adolescence, 39(156), 725734.

https://ir.nctu.edu.tw/handle/11536/14421 